\title{
Factors Influencing the Identification of Sustainable Opportunities by SMEs: Empirical Evidence from Zambia
}

\author{
Progress Choongo ${ }^{1}$, Elco Van Burg ${ }^{1, *}$, Leo J. Paas ${ }^{2}$ and Enno Masurel ${ }^{1}$ \\ Received: 17 October 2015; Accepted: 12 January 2016; Published: 15 January 2016 \\ Academic Editors: Tom Vanacker, Yves Fassin and Mirjam Knockaert \\ 1 Department of Management and Organization, Faculty of Economics and Business Administration, \\ Vrije Universiteit Amsterdam, De Boelelaan 1105, Amsterdam 1081 HV, The Netherlands; \\ p.choongo@vu.nl (P.C.); e.masurel@vu.nl (E.M.) \\ 2 School of Communication, Journalism and Marketing, College of Business, Massey University, \\ Private Bag 102904, North Shore, Auckland 0745, New Zealand; 1.j.paas@massey.ac.nz \\ * Correspondence: j.c.van.burg@vu.nl; Tel.: +31-20-598-2510
}

\begin{abstract}
This study uses the model of Patzelt and Shepherd (2011) to examine the factors influencing the identification of sustainable opportunities among SMEs in a developing country, Zambia. The factors under investigation include knowledge of the natural/social environment, perception of threats to the natural/social environment, altruism towards others and entrepreneurial knowledge. We interviewed 220 owner-managers in the trading and service sector who supply goods and services to the mining industry in Zambia. We found that altruism towards others was partially supported by our empirical results while the positive effects of knowledge of the natural/social environment and perception of threats to the natural/social environment on the identification of sustainable opportunities were not supported. Contrary to our expectations, entrepreneurial knowledge does not positively moderate the relationship between explanatory variables and the identification of sustainable opportunities. In sum, we found only limited empirical support for the model of Patzelt and Shepherd (2011) concerning the identification of sustainable opportunities. Our findings contribute to literature on entrepreneurship and sustainable opportunity identification by showing what factors influence the identification of sustainable opportunities. This can help us to create awareness among entrepreneurs regarding the effects of entrepreneurial activities on the environment and society; consequently, stimulating entrepreneurs to identify sustainable opportunities.
\end{abstract}

Keywords: sustainable entrepreneurship; sustainable opportunities; opportunity identification; SMEs; developing countries; Zambia

\section{Introduction}

In recent years, research on sustainable entrepreneurship has generated wide interest [1-3]. Entrepreneurship is concerned with the identification, evaluation and exploitation of opportunities [4]. Yet, certain entrepreneurial activities cause pollution, pose risk and damage to nature and human health. Recent findings reveal global effects that include climate change, ozone layer depletion and disruption of aquatic life $[2,5,6]$. In Sub-Saharan Africa, climate change, global warming and rainfall deficit impacted negatively on crop production and food security and reduce national welfare [7-9]. Entrepreneurship is viewed as a solution for environmental and social issues [10]. Entrepreneurial action can preserve ecosystems, counter climate changes, improve fresh air supply and agriculture practices and maintain biodiversity [11,12]. 
The role of sustainable entrepreneurship in addressing environmental and social concerns is reflected in an increasing number of studies (e.g., [13-16]). However, as most scholars have studied sustainable entrepreneurship in the western context, very little is known about sustainable entrepreneurship in developing countries. Specifically, the number of published papers on sustainable entrepreneurship in Africa is low [17-19]. Developing countries have different characteristics compared to developed countries [20], and this renders it less obvious that established theories, empirical results and methodologies from developed countries are directly applicable to the unique social, political, and economic context of developing countries [21]. Additionally, much of the current literature on sustainable entrepreneurship is more prescriptive than descriptive [10] as most contributions have remained conceptual [14]. For example, Patzelt and Shepherd 2011 [12] developed a model that suggests entrepreneurs will more likely identify sustainable opportunities as their knowledge of ecological and social environments increases, when they perceive that their ecological and social environment is threatened, and if they are more altruistic towards others. However, these propositions have not been empirically tested, and thus there is a need to empirically test such sustainable entrepreneurship theories [14].

This study aims to contribute to the sustainable entrepreneurship and opportunity identification literature. The study extends the conceptual work of Patzelt and Shepherd 2011 [12] by empirically examining the factors influencing the identification of sustainable opportunities. The model of Patzelt and Shepherd [12] is chosen for our study because it is the only model that explicitly conceptualizes how entrepreneurs identify sustainable opportunities. The model recently received attention in the literature (e.g., [22]) as it pays explicit attention to key drivers of the identification of sustainable opportunities, in particular to environmental knowledge and altruistic motivations. Yet, the relationships in the model are not explicitly tested, and therefore this study aims at advancing understanding sustainable entrepreneurship by testing factors influencing the identification of sustainable opportunities. Therefore, the research question addressed in this paper is: Which factors influence the identification of sustainable opportunities?

This study is conducted in a developing country, Zambia, because in this setting the sustainability concerns are evident and there is almost no external and government pressure or incentive to behave in a sustainable manner. As such, this setting provides an ideal context to test this model, as sustainability would be largely driven by the entrepreneurs' choice rather than influenced by external pressures. Despite these characteristics, no other known sustainable opportunity identification studies have been done in Africa. The findings and perspectives from Zambia will advance understanding what factors influence the identification of sustainable opportunities in sub-Saharan Africa which will enable us to refine, revise and extend sustainable entrepreneurship theory.

This paper proceeds as follows. First, we define the concepts of sustainable development and sustainable entrepreneurship. Second, we discuss SMEs and sustainable entrepreneurship, and then opportunity identification. Third, we review the model of Patzelt and Shepherd 2011 [12]. Fourth, we explain the research methodology, and present and discuss the results of our empirical tests. The paper will end with conclusions, and describe areas for future research.

\section{Literature Review}

\subsection{Sustainable Development and Sustainable Entrepreneurship}

Sustainable development, also referred to as sustainability $[2,23,24]$ is defined as: "the development that meets the needs of the present without compromising the ability of future generations to meet their own needs" [25] (p. 37). It implies economic growth that integrates protection of the environment and meeting human social needs. Sustainable development encompasses the three aspects of sustainability: economic, environmental and social; also referred to as the triple " $\mathrm{P}$ "planet, and profit $[26,27]$. Relatedly, the concept of sustainable entrepreneurship is derived from sustainable development and aims to balance the economic, social, and environmental objectives 
of the firm [28]. There are many definitions of sustainable entrepreneurship (see $[2,13,28-33]$ and the summary in Appendix 1). While these definitions capture the environmental and social aspects of sustainability, three definitions $[13,30,32]$ go further to incorporate opportunity identification. Opportunity identification is a central aspect of entrepreneurship [4,6]. In particular, Patzelt and Shepherd [12] (p. 632) define sustainable entrepreneurship as: "the discovery, creation, and exploitation of opportunities to create future goods and services that sustain the natural and/or communal environment and provide development gain for others". This study adopts this definition, because it maintains the main aspects of sustainable entrepreneurship, and does include the opportunity identification aspect which is a central aspect of entrepreneurship and also the focus of our study. We note that definitions by [13,32] are also appropriate for our study.

Sustainable entrepreneurship has been studied from a number of different fields; hence there is an ambiguous use of the terminology and there are several themes [10]. Common themes include sustainability entrepreneurship [34], sustainable entrepreneurship [28,33], environmental entrepreneurship $[5,15]$ ecopreneurship and green management $[35,36]$. Consequently, there are many models of sustainable entrepreneurship. However, most available models have only focused on the environmental aspect of sustainable entrepreneurship (e.g., [2,5,15,32]). We choose to empirically test the model of Patzelt and Shepherd 2011 [12], which has not been tested empirically before, for two reasons. First, while others (e.g., $[3,13,37]$ ) incorporate the environmental and social dimensions of sustainable entrepreneurship in their studies, they provide no insights in sustainable opportunity identification. The model of Patzelt and Shepherd [12] is the only model that explicitly conceptualizes how entrepreneurs identify sustainable opportunities, using as explanatory variables important concepts from previous studies such as entrepreneurial knowledge, environmental knowledge and altruistic motivations. Second, the model combines the environmental and social dimension of sustainable entrepreneurship, which makes it a promising model to study sustainable entrepreneurship as a broad concept. Thus, the model brings in new concepts and insights that are not yet empirically tested. Research on the identification of sustainable opportunities is in its infacy and therefore further empirical study on factors influencing the identfication sustainable opportunities is needed.

Empirical testing is in particular warranted because much of the extant literature on sustainable entrepreneurship is conceptual or based on small-scale case studies. For example, Cohen and Winn [32] and Dean and McMullen [2] conceptualized how market imperfections (i.e., inefficiencies, externalities, information asymmetric, flawed pricing mechanisms, government intervention, and monopolies) result in environmental degradation, consequently producing conditions in which entrepreneurs can earn profit by reducing environmental degradation. They highlight that these market imperfections yield opportunities for sustainable entrepreneurship [10]. A different conceptual model [5] theorizes how entrepreneurial action can address environmental degradation, provides innovation and engages in resource allocation to address environmental problems.

Other studies on sustainable entrepreneurship are case studies. For example, by comparing four cases, Parrish [16] found that the organizational design standards adopted by entrepreneurs concerned with sustainability differ from those of other entrepreneurs. Yet, Crals and Vereek [28] showed in another case study, that entrepreneurs need to carefully plan how they can engage in such activities, as time is a constraint for SMEs to engage in sustainable activities. Focusing on sustainability reporting, Borga et al. [38] studied seven cases of SMEs in the Italian furniture sector and found that existing reporting guidelines were mainly created for large firms; hence some elements considered in the guidelines are not appropriate for SMEs. They suggest that SMEs require appropriately designed reporting guidelines in simple language in order for them not to rely on external consultants for interpretation, while another study further suggests the need for SMEs to select simple sustainability reporting guidelines tailored to their needs [28]. 
Yet, only a few quantitative, large-scale studies have focused on sustainable entrepreneurship, and empirical testing of developed conceptual models is lagging behind. Recent quantitative studies have tested the effect of social norms and state-level incentives on founding sustainable entrepreneurial firms [15]. That this founding stage is important, is demonstrated in another study that found that new entrants (small firms recently founded) are more likely than incumbents (large firms who tend to be old) to pursue sustainable opportunities [13]. Older firms are usually less eager to pursue environmental and social objectives because they have established markets. They [13] developed a model that shows that sustainable entrepreneurship in organizations is going to be initiated by both the incumbents and new entrants.

While existing literature contributes key insights in sustainable entrepreneurship, most of the studies are conceptual and theoretical [14] or focus on the development process of a sustainable firm. Developed conceptual models are hardly empirically tested and few have focused on how existing firms identify sustainable opportunities. Thus, there is need to move our understanding beyond theorizing to empirically testing the sustainable entrepreneurship concepts [14], with larger data sets, and in different contexts.

\subsection{SMEs and Sustainable Entrepreneurship}

Although environmental and social issues have been often researched in large organizations, SMEs have received limited attention. SMEs are suitable for this research for two reasons. First, SMEs form the majority of business establishments [39]. For example in Zambia, this sector consists of approximately $97 \%$ of all enterprises [40]. Moreover, SMEs are often associated with environmental degradation, pollution and depletion of non-renewable energy sources. Cumulatively, SMEs contribute $70 \%$ to global pollution [41,42]. Thus, scholars and policy makers have recognized that small firms can play an important role in finding solutions to environmental problems [40]. Therefore, given their large numbers worldwide, SMEs can play an essential role in driving the sustainable development agenda forward. They are more flexible and closer to their customers than large firms, and could therefore respond quicker and more effective to environmental and social problems [43].

Despite their potential to affect the environment and society, most SMEs are slow in developing and implementing sustainability [41,43]. Environmental awareness and action is low among small firms [44]. SMEs are generally managed by their owners, are largely local [45] and lack formal structures with specialized staff; this influences their approach in dealing with sustainability issues [46]. Entrepreneurs are often ignorant of their environmental impact, have limited resources to tackle environmental issues, and are unwilling to take action due to time- and resource constraints [41,47]. Yet, the idea of sustainability seems to drive some SMEs, as Rodgers [35] found that in the UK sustainable entrepreneurs look for social change apart from financial change. They have ethical principles and values, are risk tolerant, and seek knowledge on sustainability issues. Also Kearins et al. [48] found evidence of business-nature relationships aligned with ecological paradigms in a study of three SMEs in New Zealand. In general, smaller and younger firms appear to be better at integrating sustainability into their business objectives than older firms [29].

The focus of sustainability studies has been on environmental issues whilst the social aspects have been rarely examined [49]. In Africa and other developing countries, sustainable entrepreneurship research on SMEs has often focused mainly on environmental and corporate social responsibility (CSR). For instance, in Nigeria, the perception of managers of small firms towards sustaining the environment appears to be negative [50]. In contrast, the environmental attitude of owner-managers of SMEs seems to be positive [51]. Amaeshi et al. [52] even found that indigenous Nigerian firms' practice of CSR is altruistic and philanthropic. These authors suggested that goodness to society and charity is the moral economy of kin-based solidarity and reciprocity, and thus there should be a clear link between responsibility for natural and social aspects of the environment. As such, social entrepreneurship appears to be prevalent in many African countries in such a way that the entrepreneurs feel responsible for their own employees, their families and the wider community [53]. 
Similarly, in the study of 1300 SMEs in eight countries in Latin America, sustainability practices appear to be related to employees although less to the community and the environment [54]. Thus, there appears to be a link between sustaining the natural and the social environment.

\subsection{Opportunity Identification}

Entrepreneurship is concerned with the identification, evaluation and exploitation of opportunities [4]. Casson [55] defines entrepreneurial opportunities as situations in which new services, goods, raw materials, organizing methods and markets can be introduced and sold at a revenue. Sustainable opportunities are different in that while entrepreneurial opportunities focus on profit, sustainable opportunities seek to sustain the natural and/or social environment and provide development gains for the entrepreneurs and for others [12]. Development gain for others comprises economic gain, environmental gain and social gain for society [56]. The natural dimension of sustainable opportunities includes environmental care, eco-efficiency, clean products, sustainable technology, and eco-design, while the social dimension of sustainable opportunities concerns people-care for employees and society [28]. Opportunity identification has been measured as the number of new opportunities or new parts of a business pursued in the past five years [57].

In general, factors influencing opportunity identification include alertness, cognition, creativity, extrinsic motivation, financial reward, human capital, learning, networks, prior knowledge [56], prior experience [58] and prior business experience [59]. The latter factors are found to be very important; entrepreneurs identify opportunities related to the information they possess [60].

Prior knowledge refers to an individual's knowledge about a particular matter and helps him/her to identify particular opportunities [57,61], in a way that those lacking this information cannot depict [61]. Shane [60] found that entrepreneurs identify particular opportunities because of their idiosyncratic prior knowledge. This knowledge can be gained from work-experience, education, experiential learning and other means. According to human capital theory, knowledge increase in a certain field allows individuals to become efficient in information processing, such that they focus on the critical dimensions for the positive outcomes of their decisions [61]. Prior knowledge helps to integrate and accumulate new knowledge, thereby giving individuals a larger opportunity set [57]. Opportunity creation may also be enhanced by knowledge resulting from previous entrepreneurial experience [62]. Habitual entrepreneurs with previous business ownership identify a larger number of business opportunities than novice entrepreneurs [63]. Consistent with these inferences about the effect of prior knowledge, Cooper and Park [64] found that knowledge and an entrepreneur's work experience play a central role in the recognition and exploitation of innovative new product technologies. Similarly, Alsos and Kaikkonon [58] found that the process of opportunity creation is related to the entrepreneurs' extensive experience from prior employment, prior business activities, and hobbies. While prior experience leads to the identification of larger numbers of opportunities, the positive effect of the identification of sustainable opportunities vanishes as business experience increases. Learning from experience causes entrepreneurs to evaluate opportunities more rigorously; thus, the number of perceived opportunities may decline with business and experience [14].

Despite the fact that the study of prior knowledge provides significant insights to the identification of entrepreneurial opportunities, there has been limited empirical research on the effect of prior knowledge on the identification of sustainable opportunities. The direct effects of conventional entrepreneurial knowledge found in previous studies are insufficient to explain the identification of sustainable opportunities [12]. Additionally, Patzelt and Shepherd [12] propose that the knowledge of the natural/social environment also plays a key role for sustainable opportunity identification.

\subsection{The Model of Patzelt and Shepherd (2011)}

This study builds on the model of Patzelt and Shepherd [12] of the identification of sustainable development opportunities (referred to in this paper as sustainable opportunities)—see Figure 1. The main variables of this model are: (1) recognition of sustainable opportunities as a dependent 
variable; (2) three explanatory variables: knowledge of the natural/social environment, perception of threats of the natural/social environment and altruism towards others; and (3) entrepreneurial knowledge as a moderator variable.

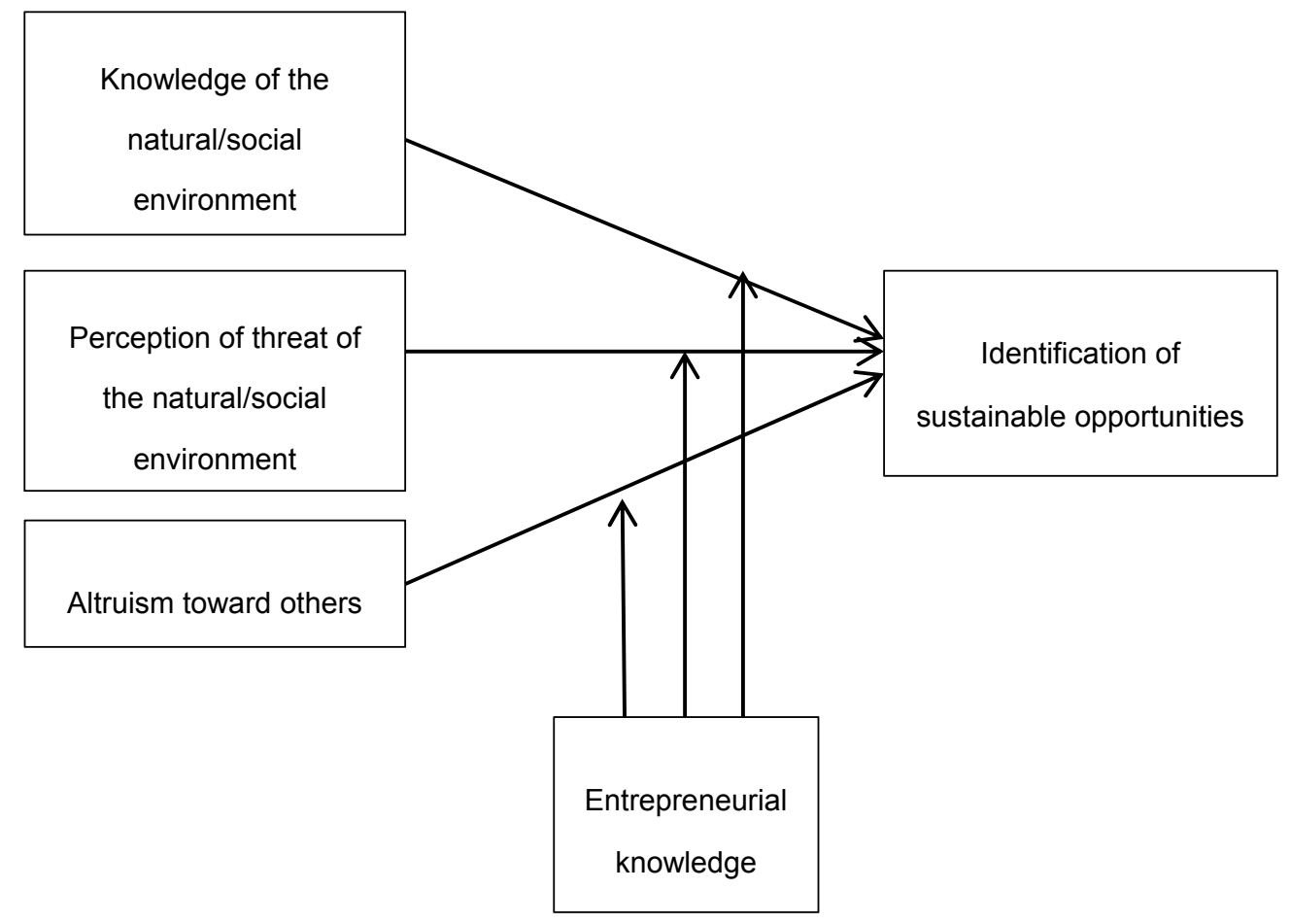

Figure 1. Identification of sustainable opportunities [12].

Patzelt and Shepherd [12] suggested that entrepreneurs are more likely to identify sustainable opportunities if they have knowledge of the natural/social environment, if they perceive that the natural/social environment is threatened, and if they are more altruistic. Furthermore, they suggested that entrepreneurial knowledge moderate the relationship between the three explanatory variables and the identification of sustainable opportunities. It is important to note that while authors such as Gray et al. [22] have extended the model of Patzelt and Shepherd [12] by including other variables such as institutional factors, incidents and social embeddedness, the original model is still not empirically tested. There have not yet been empirical tests on whether the available model can or cannot predict the recognition of sustainable opportunities; empirical testing of the proposed concepts is needed before we can add other variables. By first testing the model in this study, it will be clear which of the factors proposed explain how sustainable opportunities are identified. Later, follow-up studies can add other relevant variables that may influence sustainable opportunity identification. Therefore, as a starting point to test sustainable opportunity identification concepts, we chose the model of Patzelt and Shepherd [12] as a well-received newly developed, yet untested, model [22], focused on the identification of sustainable opportunities.

\section{Hypotheses}

\subsection{Knowledge of the Natural/Social Environment}

Awareness of sustainability is an important driver for sustainable innovation [28]. Similarly, Patzelt and Shepherd [12] argue that awareness or knowledge of the natural environment (e.g., earth, biodiversity, ecosystems, overfishing; sources of soil, air and water pollution) and social knowledge (e.g., culture, health and life expectancy) influences the identification of sustainable opportunities. Therefore, education for sustainable development appears to be especially valuable for nascent 
entrepreneurs because enhancing their knowledge about sustainable entrepreneurship may have an effect on their ability to identify sustainable business opportunities [23]. This is confirmed by a study by Rodgers [35], who in a study of three UK-based SMEs, found that some entrepreneurs started sustainable enterprises after increasing their knowledge through "green" education. In particular, one owner-manager increased her knowledge of the natural environment by spending two full years conducting her own research into sustainable building before launching her firm. Similarly, knowledge of social difficulties and problems in a community can be a source for the identification of sustainable opportunities [65]. Thus, it is hypothesized that:

- H1: The entrepreneurs' knowledge of the natural/social environment is positively associated with the identification of sustainable opportunities.

\subsection{Perception of Threat to the Natural/Social Environment}

Natural resource degradation, pollution, and loss of biodiversity increase vulnerability and reduce the well-being of people and animals [66]. When individuals perceive that their physical and psychological well-being is threatened, they direct their attention towards sustaining the natural/social environment. Threats cause individuals to take a defensive posture [67]. Thus, it is proposed that:

- H2: The entrepreneurs' perception of threat to their natural/social environment is positively associated with the identification of sustainable opportunities.

\subsection{Altruism Towards Others}

Altruism is understood as an individual's motivation to enhance the welfare of other people without conscious regard of one's self-interest [68,69]. Altruistic individuals are generally more generous, helping, and kind than others. The feelings of empathy and sympathy for other people make up altruistic motivations that aim to improve the welfare of the individuals in need. For example, people who empathize with the poor in society may experience their grief; consequently motivating empathetic individuals to find sustainable opportunities that improve poor people's situation. Similarly, individuals who sympathize with the poor will understand their sorrows and will be motivated to help them by attending to opportunities that change their situation. Similarly, individuals who experience empathy and sympathy for animals can identify opportunities that may improve the environmental condition in which the species live. These situations trigger the identification of sustainable opportunities, especially with a focus on the social aspect of these opportunities [12]. This leads to the following hypothesis:

- H3: The entrepreneurs' altruism towards others is positively associated with the identification of sustainable opportunities.

\subsection{Entrepreneurial Knowledge}

As already stated, entrepreneurial knowledge plays a major role in the identification of sustainable opportunities. Identifying opportunities to sustain the natural/social environment requires individuals to associate their knowledge of the environment with their prior entrepreneurial experience (i.e., knowledge of the markets, ways to serve the markets, and dealing with customer's problems). Therefore, entrepreneurial knowledge moderates the extent to which knowledge of the natural/social environment contributes to the identification of sustainable opportunities [12].

When an individual perceives a threat, he or she tends to seek opportunities to escape from it. For example, an individual living in a city where car emissions and pollution threaten his or her health and that of others will be more likely to seek opportunities to escape that threat and improve air quality. Using his or her knowledge of the local car market (knowledge of markets) and ways to serve the markets, that individual may identify an opportunity to open a "green car" market, thereby solving customers' problems [12]. It is therefore expected that entrepreneurial knowledge moderates the extent 
to which perception of threats to the natural/social environment contributes to the identification of sustainable opportunities.

Entrepreneurial knowledge enhances the identification of sustainable opportunities amongst entrepreneurs with altruism. This is because knowledge of the markets will direct the mind of altruistically motivated entrepreneurs towards entrepreneurial activities that develop economic, environmental and social value [12]. It is therefore hypothesized that:

- H4a: Entrepreneurial knowledge has a positive moderating effect on the association of entrepreneurs' knowledge of the natural/social environment with the identification of sustainable opportunities.

- H4b: Entrepreneurial knowledge has a positive moderating effect on the association of the entrepreneurs' perception of threats to the natural/social environment with the identification of sustainable opportunities.

- H4c: Entrepreneurial knowledge has a positive moderating effect on the association of entrepreneurs' altruism towards others with the identification of sustainable opportunities.

\section{Methodology}

\subsection{Study Context: Zambia}

The empirical study is conducted in the Zambian mining industry. The country is appropriate for this study because of its dependency on the mining industry which contributes significantly to pollution, and thus gives a direct and well-known environmental threat, even though this sector is also known to be active in addressing environmental and social concerns. The findings can be applied to other industries as well as to other developing countries with mining industries (minerals, gas and oil) like Angola, Botswana, Libya and Nigeria. The research is also important for SMEs in developing countries who sell goods and products to the large multinational firms (mining included) because failure to meet the environmental and social aspects can lead to loss of contracts from large firms who take environmental measures [70]. The mining and processing of copper is the largest industry in Zambia, representing 70\% of export earnings in 2011 [71]. The mining industry attracts a large number of contractors and suppliers of goods and services. The major mining companies buy about US\$2 billion of goods and services from Zambian businesses annually. In 2012, the major mining companies invested US\$70 million in 200 community programs around the mine sites. The mining companies do also run schools, health care centers and hospitals [71].

This study's focus on sustainable entrepreneurship in a developing country provides an excellent setting to test sustainable entrepreneurship theories. For the definition of developing countries see Appendix 2 [72]. Developing countries have different characteristics compared to developed countries, as they are for instance characterized by rapid structural changes in socio-economic institutions [73]. The environmental, social and governance risk faced by developing countries varies from country to country. For example, in emerging countries like Brazil, deforestation and interaction with indigenous people are a major concern. In China, depletion of water resources and air pollution are more critical concerns [74,75]. In Africa, environmental and social challenges include environmental degradation, natural resource depletion, poverty, disease, poor infrastructure, unemployment, and overfishing [76]. Moreover, most of the vehicles imported are second hand, this leads to increased emission of gas, and deteriorating air quality linked to industrial emissions [77].

In Zambia key environmental issues include: drought, floods, extreme heat, and shortage of raw materials. Particularly, sulphur dioxide on the Copperbelt province is a well-known problem due to smelting of copper and roasting of cobalt, hence acceptable air pollution limits are often exceeded. These risks may eventually impact agriculture and food security, natural resources, world life, forestry, human health, water supply and energy [78]. In 1992, Zambia Environmental Management Agency (ZEMA), a regulatory body was established to promote sustainable development, environmental management, conservation, protection, sustainable management and use of resources. 


\subsection{Sample and Data Collection}

The sample for the study was selected from databases of the four major mining companies in Zambia_these are Kansanshi Mine, Konkola Copper Mines, Lumwana Mine and Mopani Copper Mines. We selected SMEs that operate in the trading and service sectors and are registered as suppliers and contractors of the four major mining firms. The nature of goods supplied is divided into three categories, namely (1) durable or manufactured products, such as electrical appliances, industrial cleaning machines, pipes, valves, motors, protective clothing, timber; (2) consumables, like electrodes, paints, cleaning materials; and (3) services, like repair and maintenance of plants, buildings and equipment, security and consultancy. Suppliers and contractors in the mining sector were considered suitable for this study because the sector is known to be active in environmental and social concerns. The selection of firms was based on firm size-we selected firms with numbers of employees ranging from 10 to 250 . The database of firms in the construction sector had about 1200 firms that met these conditions. We first randomly selected 350 firms for our study. When we tried to contact them, we experienced difficulties as some telephone numbers were not going through, others had closed or changed location. Apparently the database was not updated for a long time. Therefore, for the subsequent field work, convenience sampling was used based on whether we could access the firms. As an example, during field work, when we visited a premise of one of the 350 randomly selected firms, and found a different company from the list, we also surveyed that firm. Respondents also helped us by referring us to other firms. Through this sampling process, questionnaires were administered to 320 SMEs. We assured geographical representation of the sample by selecting firms located in different towns. Previous studies have encountered similar difficulties in collecting data in developing countries, and therefore Kriauciunas et al. [79] recommend that the sampling frame and the survey administration techniques need to be context-specific. Hence, also face-to-face questioning, emailing and dropping off questionnaires and picking up were used. This combination of methods resulted in 230 responses, but only 220 respondents completed all questions in our survey, resulting in a $68.8 \%$ response rate. The questionnaires were conducted with owner-managers or managing directors for firms where the owner-managers were not available. The sample was composed of 185 males (84.1\%) and 35 females (15.9\%).

\subsection{Measures}

As a pre-study, we conducted 12 expert interviews with business associations, consultants, regulatory bodies and entrepreneurs. The purpose of interviewing these individuals was to (1) assess what other variables could be added to the Patzelt and Shepherd [12] model; (2) assess whether sustainability was a relevant issue in Zambia; and (3) identify important sustainable entrepreneurship variables. The subsequently developed questionnaire was pre-tested prior to data collection with four subject experts from academia and two experienced entrepreneurs. The pre-test was to check if the questions were clear. We experienced that six pre-test interviews were sufficient as only minor changes were made to the initial questions. Based on the pre-test, three items on the altruism scale were modified to the context under study. For example, "I have helped push a stranger's car out of the snow" is not applicable in the Zambian context and was adjusted to "I have helped push a stranger's car". The other measurement scales did not require adaptation because the concepts were clear, readable and understandable. Details of all measurement scales and scale validation are provided in Table 1. 
Table 1. Survey questions and scale validation.

\begin{tabular}{|c|c|c|c|c|c|}
\hline \multicolumn{6}{|c|}{ Knowledge of the Natural/Social Environment } \\
\hline Factor Loadings & Factor 1: Knowledge of the Natural Environment & Cronbach's $\alpha$ & Factor Loadings & Factor 2: Knowledge of the Social Environment & Cronbach's a \\
\hline 0.681 & $\begin{array}{l}\text { I have rich knowledge about sustaining the nature } \\
\text { (i.e., earth, biodiversity, and ecosystem). }\end{array}$ & & 0.746 & $\begin{array}{l}\text { I understand the culture of different tribes in } \\
\text { my country. }\end{array}$ & \\
\hline 0.868 & $\begin{array}{l}\text { I know the potential sources of soil, air and } \\
\text { water pollution. }\end{array}$ & 0.692 & 0.842 & $\begin{array}{l}\text { I have rich knowledge about social issues in the } \\
\text { current society. }\end{array}$ & 0.710 \\
\hline 0.735 & $\begin{array}{l}\text { I am aware that overfishing leads to decline of } \\
\text { fish stocks. }\end{array}$ & & 0.725 & $\begin{array}{l}\text { I am aware of the difficulties that disabled people } \\
\text { have in our society. }\end{array}$ & \\
\hline \multicolumn{6}{|c|}{ Perception of threat to the Natural/Social Environment } \\
\hline Factor Loadings & Factor 1: Biospheric concerns & Cronbach's $\alpha$ & Factor Loadings & Factor 2: Egoistic concerns & Cronbach's $a$ \\
\hline 0.762 & Plants & & 0.759 & $\mathrm{Me}$ & \\
\hline 0.819 & Marine Life & & 0.765 & My Life style & \\
\hline 0.901 & Birds & 0.893 & 0.712 & My health & 0.825 \\
\hline 0.672 & Animals & & 0.676 & My future & \\
\hline Factor Loadings & Factor 3: Social concerns & Cronbach's $\alpha$ & & & \\
\hline 0.826 & People in the community & & & & \\
\hline 0.878 & All people & 0.917 & & & \\
\hline 0.849 & Children & & & & \\
\hline 0.788 & Future generations & & & & \\
\hline \multicolumn{6}{|l|}{ Altruism } \\
\hline Factor Loadings & Factor 1: Inclination to Making Efforts for others & Cronbach's $\alpha$ & Factor Loadings & Factor 2: Inclination to Donating Charity & Cronbach's $a$ \\
\hline 0.601 & $\begin{array}{l}\text { I have delayed a bus and held the door open } \\
\text { for strangers. }\end{array}$ & & 0.758 & I have given money to charity. & \\
\hline 0.633 & $\begin{array}{l}\text { I have helped a classmate whom I did not know } \\
\text { well with a homework assignment when my } \\
\text { knowledge was greater than his/hers. }\end{array}$ & & 0.779 & I have donated goods or clothes to a charity. & 0.786 \\
\hline 0.693 & $\begin{array}{l}\text { I have, before being asked, voluntarily looked after } \\
\text { a neighbor's children without being paid for it. }\end{array}$ & & 0.719 & I have done volunteer work for charity. & \\
\hline 0.626 & $\begin{array}{l}\text { I have offered to help a handicapped or elderly } \\
\text { stranger across a street. }\end{array}$ & 0.819 & & & \\
\hline
\end{tabular}


Table 1. Cont

\begin{tabular}{|c|c|c|c|}
\hline \multicolumn{4}{|c|}{ Knowledge of the Natural/Social Environment } \\
\hline Factor Loadings & Factor 1: Inclination to Making Efforts for others & Cronbach's $\alpha$ & Factor 2: Inclination to Donating Charity \\
\hline 0.712 & $\begin{array}{l}\text { I have offered my seat on a bus or train to a stranger } \\
\text { who was standing. }\end{array}$ & & Items deleted \\
\hline 0.694 & I have helped an acquaintance to move households. & & $\begin{array}{l}\text { I have changed money for a stranger. } \\
\text { I have donated blood. }\end{array}$ \\
\hline Factor Loadings & Factor 3: Inclination to Helping Strangers & Cronbach's $\alpha$ & I have helped carry a stranger's belongings. \\
\hline 0.612 & I have helped push a stranger's car. & & I have allowed someone to go ahead of me in a lineup. \\
\hline 0.774 & I have given directions to strangers. & 0.682 & $\begin{array}{l}\text { I have pointed out a clerk's error (in a bank, at the supermarket) in undercharging me for } \\
\text { an item. }\end{array}$ \\
\hline 0.549 & $\begin{array}{l}\text { I have given money to strangers who asked me } \\
\text { for it. }\end{array}$ & & $\begin{array}{l}\text { I have let a neighbor whom I didn't know too well borrow an item of some value to me } \\
\text { (e.g., tools, a dish, etc.). }\end{array}$ \\
\hline 0.574 & I have given a stranger a lift in my car. & & $\begin{array}{l}\text { I have bought "charity" Christmas cards / gifts deliberately because I knew it was a } \\
\text { good cause. }\end{array}$ \\
\hline \multicolumn{4}{|c|}{ Entrepreneurial knowledge } \\
\hline $\begin{array}{l}\text { Factor Loadings } \\
0.869\end{array}$ & $\begin{array}{l}\text { Factor 1: Entrepreneurial Knowledge } \\
\text { I know how to serve markets. }\end{array}$ & Cronbach's $\alpha$ & \\
\hline 0.909 & $\begin{array}{l}\text { I am familiar with customer problems. } \\
\text { I have rich knowledge about markets such as } \\
\text { supplier relationships, sales techniques, capital } \\
\text { equipment retirement, etc. }\end{array}$ & 0.849 & \\
\hline
\end{tabular}




\subsubsection{Dependent Variable}

The study includes one dependent variable: Opportunity identification. Opportunity identification was measured in terms of the number of sustainable opportunities perceived by respondents and was adapted from [59]. In the original model by [59], respondents were asked: "How many opportunities for creating or purchasing a business have you identified in the last five years?" We adapted and modified this question by asking respondents: "How many opportunities for making your business more sustainable and/or starting a sustainable businesses have you identified within the last five years?" Respondents were asked to indicate the category that fits the number of opportunities they identified from the following eight categories $(0,1,2,3,4,5,6-10$, and more than 10 opportunities). Respondents who identified zero opportunities were allocated a score of " 1 ", a score of "2" for those who identified one opportunity, " 3 " for two opportunities, " 4 " for three opportunities, " 5 " for four opportunities, " 6 " for five opportunities, " 7 " for six to 10 opportunities, and " 8 " for more than 10 opportunities (see [59]). In our sample three respondents (1.4\%) identified zero sustainable opportunities, five (2.3\%) one opportunity, nine (4.1\%) two opportunities; $26(11.8 \%)$ three opportunities; 31 (14.1\%) four opportunities; 47 (21.4\%) five opportunities; 82 (37.2\%) six to 10 opportunities; $17(7.7 \%)$ identified more than 10 opportunities. Overall, $98.6 \%$ of the respondents identified at least one opportunity. The eight opportunity identification categories were collapsed into two categories: low opportunity identification (identifying less than six opportunities) and high opportunity identification (identifying at least six opportunities), because some categories were infrequently selected and also to improve estimation $[59,80]$. As a result, $52.2 \%$ were in the low opportunity category and $44.8 \%$ in the high category. The mean on this collapsed variable is $44.8 \%$ which gives an overall indication of low sustainable opportunity identification (see Table 2).

To check whether respondents understood the meaning of sustainable opportunity, we asked them to give examples of sustainable opportunities they had identified. For example, some respondents indicated that they started to use high pressure cleaning machines which avoids using chemicals to clean heavy duty cleaning machines. Other examples include opportunities related to energy saving, water service, and recycling. Examples of social opportunities include care for the employees by providing safe working environment for employees, paying funeral grants, providing transport to mourners in their community, buying fuel for police vehicles in their communities, and paying medical bills for their employees. Thus, they saw opportunities to strengthen their business alongside providing social support. Examples of society based sustainable opportunities include sponsoring community based projects, sports, traditional ceremonies, building community schools for the underprivileged, support orphanages, digging wells for safe drinking water, repairing roads, providing industrial attachments, and creating HIV awareness. 
Table 2. Descriptive statistics and correlation matrix.

\begin{tabular}{|c|c|c|c|c|c|c|c|c|c|c|c|c|c|c|c|c|}
\hline & Mean & SD & VIF & 1 & 2 & 3 & 4 & 5 & 6 & 7 & 8 & 9 & 10 & 11 & 12 & 13 \\
\hline (1) Sustainable Opportunities Identification & $44.8 \%$ & 0.50 & & 1.000 & & & & & & & & & & & & \\
\hline (2) Age & 2.10 & 0.56 & 1.43 & -0.063 & 1.000 & & & & & & & & & & & \\
\hline (3) Gender & 1.84 & 0.37 & 1.08 & -0.056 & 0.121 & 1.000 & & & & & & & & & & \\
\hline (4) Education & 2.38 & 0.51 & 1.08 & 0.022 & -0.006 & 0.083 & 1.000 & & & & & & & & & \\
\hline (5) Entrepreneurial Knowledge & 3.91 & 0.66 & 1.41 & 0.132 & -0.016 & 0.058 & 0.095 & 1.000 & & & & & & & & \\
\hline (6) Knowledge of Natural Environment & 3.90 & 0.63 & 1.63 & 0.083 & -0.006 & 0.088 & -0.035 & $0.284^{* *}$ & 1.000 & & & & & & & \\
\hline (7) Knowledge of Social Environment & 3.97 & 0.58 & 1.57 & 0.097 & 0.006 & 0.031 & -0.059 & $0.424 * *$ & 0.463 ** & 1.000 & & & & & & \\
\hline (8) Threat Biosphere & 5.88 & 1.17 & 1.87 & -0.102 & 0.065 & 0.005 & 0.025 & 0.096 & $0.325^{* *}$ & 0.114 & 1.000 & & & & & \\
\hline (9) Threat Egoistic & 6.43 & 0.70 & 2.32 & -0.143 & -0.113 & -0.019 & 0.039 & $0.276^{* *}$ & $0.314^{* *}$ & $0.346^{* *}$ & $0.487^{* *}$ & 1.000 & & & & \\
\hline (10) Threat Social & 6.57 & 0.63 & 1.67 & -0.064 & -0.059 & -0.061 & 0.106 & $0.222 * *$ & $0.202 * *$ & $0.254^{* *}$ & $0.460^{* *}$ & $0.647^{* *}$ & 1.000 & & & \\
\hline (11) Inclination to Donate to Charity & 3.30 & 0.96 & 1.35 & $0.225^{* *}$ & 0.111 & -0.042 & 0.009 & $0.152 *$ & 0.130 & $0.157 *$ & 0.068 & 0.041 & 0.038 & 1.000 & & \\
\hline (12) Inclination to Helping Strangers & 2.99 & 0.75 & 1.54 & $0.152 *$ & -0.063 & -0.092 & -0.018 & 0.057 & -0.012 & 0.137 & 0.0 .079 & 0.058 & 0.010 & $0.343^{* *}$ & 1.000 & \\
\hline (13) Inclination to Make effort others & 3.22 & 0.84 & 1.91 & 0.196 & -0.076 & -0.069 & -0.036 & 0.040 & $0.229^{* *}$ & $0.218^{* *}$ & -0.005 & -0.008 & -0.021 & $0.396^{* *}$ & $0.554^{* *}$ & 1.000 \\
\hline
\end{tabular}

${ }^{* *}$ Correlation is significant at the 0.01 level (2-tailed); ${ }^{*}$ Correlation is significant at the 0.05 level (2-tailed). $N=220$. 


\subsubsection{Independent Variables}

Three independent variables were measured. Knowledge of the natural/social environment was measured on a six item scale based on the work by [12]. Three items relate to the knowledge of the natural environment and the other three relate to the knowledge of the social environment (see Table 1). All six items were measured on a 5-point scale Likert scale ranging from $1=$ Strongly disagree; 2 = Disagree; $3=$ Neutral; $4=$ Agree; and $5=$ Strongly agree .

Perception of threat to the natural/social environment was measured using a 12 item scale adopted from Schultz [81]. Respondents were asked to rate each of the items from 1 (not important) to 7 (supreme importance) when answering the question: "I am concerned about the environmental problem because of consequences for:" "plants", "marine life", "birds", "animals", "me", "my life style", "my health", "my future", "people in the community", "all people", "children" and "future generations". The measure covers sustainability problems the entrepreneur is most likely to be concerned with (planet, people and life support).

Altruism towards others was measured using Rushton et al.'s [82] 20-item Self-Report Altruism (SRA) scale. Respondents were to rate the frequency with which they have engaged in each of the 20 altruistic acts by ticking one of the following "Never", "Once", "More than once", "Often" or "Very often". Respondents who reported "Never" were allocated a score of 1, "Once" 2, "More than once" 3, "Often" 4 and "Very often" a score of 5 . This measure reflects the altruistic behavior of entrepreneurs as confirmed by experts in our study settings.

\subsubsection{Moderating Variable}

Prior entrepreneurial knowledge, was operationalized using three items from Tang and Murphy [83]. These items include "I know how to serve the markets"; "I am familiar with customers problems" and "I have rich knowledge about markets". All items were measured on a 5-point Likert scale ranging from $1=$ Strongly Disagree to $5=$ Strongly agree. This measure captures the three dimensions of knowledge which reflects the primary reasons why the entrepreneur starts a business.

\subsubsection{Control Variables}

Control variables. The following control variables were included. Education-studies show that knowledge gained from education has a key role in the opportunity identification process $[35,61]$. Education was coded " 1 " for respondents who reported "no post-secondary education"; "2" for "some post-secondary education"; and " 3 " with a "bachelor's degree or more". Age was coded in three categories: " 1 " young < 30 years; " 2 " middle-aged 31-50 years; and " 3 " old > 50 years. Regarding gender, female entrepreneurs were coded " 0 ", whilst male entrepreneurs were coded " 1 ".

\subsubsection{Scale Validation}

Exploratory factor analysis (EFA) with varimax rotation was applied for assessing the validity of the measurement scales. Table 1 shows rotated factor loadings and reliability tests for all variables. First, two factors for the knowledge of the natural/social environment scale were extracted $(\mathrm{KMO}=0.734)$, the first factor comprising three items relates to knowledge of the natural environment while the second factor with three other items relates to knowledge of the social environment. The extracted factors were consistent with our expectation that were derived from Patzelt and Shepherd [12]. Second, regarding perceptions of threats to the natural/social environment, three factors were extracted from the 12 items: the first factor composed of four items relates to biospheric concerns, the second factor with four items relates to egoistic concerns and the last factor with four items relates to altruistic concerns (we label this as "social concerns" for the purpose of this research) $(\mathrm{KMO}=0.868)$. Our results are consistent with those reported in [81].

Third, for altruism towards others, after removing seven of the 20 items that were cross loading, we retained three factors that we labeled: (1) Inclination to make an effort for others; (2) Inclination 
to donate to charity; and (3) Inclination to helping strangers ( $\mathrm{KMO}=0.827)$. These factors reflect altruistic behavior an entrepreneur and an organization is most likely to engage in. The extracted factors for the altruism scale were not similar to those reported in previous studies. There are several potential explanations for the difference in the number of factors we extracted in our data set and those extracted by other researchers in previous studies, for example [84] extracted four factors of altruism which they labeled as: public (general help publicly), social (personal help privately), charity (general help privately), and support (personal help publicly). One explanation is that previous studies on the altruism construct were conducted in a Western context. Given the cultural differences between Sub-Saharan countries and Western countries [85], it is very well possible that the dimensionality of the altruism construct differs across these contexts. For entrepreneurial knowledge, one factor was extracted $(\mathrm{KMO}=0.712)$.

All items in Table 1 had factor loadings of 0.40 or higher, the acceptable threshold for samples size between 200 and 249 [86], thereby indicating satisfactory levels of convergence and discriminant validity. The scales had sufficient reliability levels as shown by the Cronbach's alpha values in Table 1 . Most of the Cronbach's alpha variables exceed the 0.7 threshold originally suggested by Nunally [87]. For the knowledge of the natural environment and inclination to help strangers the values are slightly below this threshold, 0.692 respectively 0.682 , which is acceptable when developing new scales or applying scales in a new context [87]. The KMO values were above 0.7 , and the Bartlett's test was significant $(p=0.000)$ for each of the measurement scales, therefore our factor analysis was appropriate.

\section{Empirical Results and Discussion}

\subsection{Data Analysis}

The descriptive statistics and correlations for all variables are reported in Table 2. The variance inflation factor (VIF) scores suggest that multicollinearity is not an issue in this model. Multicollinearity refers to a high degree of correlations among independent variables. This implies that the effects of the independent variables cannot be precisely estimated [86,88]. In this case, all VIF values are below the critical value of 10 and most correlations in Table 2 are insignificant and/or of a low magnitude. This implies that the estimated effects in the logistic regression models, see Table 3, are unbiased by high correlations between independent variables. The dependent variable measured the number of sustainable opportunities identified in eight categories which were collapsed into two categories (low opportunity identification and high opportunity identification), which gives a dichotomous dependent variable. Linear regression becomes inappropriate for categorical dependent variables because it relies on the assumption of normality of residuals [89,90]. Consequently, hierarchical logistic regression analysis was used to test the hypotheses H1-H4c. Four models were estimated. The first model included control variables only. The second model incorporated all independent variables for testing hypotheses $\mathrm{H} 1, \mathrm{H} 2$, and $\mathrm{H} 3$. Model 3 included the relevant interaction terms, for assessing significance of the moderating effects of entrepreneurial knowledge (for testing $\mathrm{H} 4 \mathrm{a}$, $\mathrm{H} 4 \mathrm{~b}$ and $\mathrm{H} 4 \mathrm{c}$ ). As an example, to assess whether the relationship between knowledge of the natural environment and sustainable opportunities is moderated by entrepreneurial knowledge, we built the interaction term (Knowledge of the Natural Environment * Entrepreneurial Knowledge). Interaction terms were centered to mitigate the problems of multicollinearity in moderated regression models and to facilitate interpretations [90,91]. Model 4 incorporated the direct effects of entrepreneurial knowledge. The summary of the logistic regression results is shown in Table 3 . We checked whether an ordinal regression model using three categories for the dependent variable could be used (low: 0-3 opportunities; medium: 4-5 opportunities; high: $>5$ opportunities). This, however, led to unbalanced categories, and as a result $66.5 \%$ of the cells are empty when using this model, implying the obtained model is likely to be unstable. The results of this ordinal regression showed similar results as the logistic regression, implying that the dichotomization of the dependent variable did not influence our findings. 
Table 3. Logistics regression analysis summary assessing significance of moderating effects of prior entrepreneurial knowledge on the identification of sustainable opportunities.

\begin{tabular}{|c|c|c|c|c|}
\hline Variable & Model 1 & Model 2 & Model 3 & Model 4 \\
\hline \multicolumn{5}{|l|}{ Controls } \\
\hline Age & $-0.205(0.402)$ & $-0.389(0.150)$ & $-0.381(0.177)$ & $-0.333(0.252)$ \\
\hline Gender & $-0.282(0.451)$ & $-0.314(0.440)$ & $-0.225(0.595)$ & $-0.254(0.549)$ \\
\hline Education & $0.103(0.703)$ & $0.305(0.523)$ & $0.281(0.345)$ & $0.197(0.519)$ \\
\hline \multicolumn{5}{|l|}{ Direct effects } \\
\hline Entrepreneurial Knowledge & & & & $1.077(0.003)^{* *}$ \\
\hline \multicolumn{5}{|l|}{ Knowledge of the Natural/Social Environment } \\
\hline Knowledge of the Natural Environment & & $0.323(0.521)$ & $0.464(0.135)$ & $0.384(0.230)$ \\
\hline Knowledge of the Social Environment & & $0.353(0.245)$ & $0.529(0.106)$ & $0.276(0.416)$ \\
\hline \multicolumn{5}{|l|}{ Perception of Threats to the Natural/Social Environment } \\
\hline Threat Biosphere & & $-0.104(0.508)$ & $-0.055(0.749)$ & $-0.016(0.927)$ \\
\hline Threat Egoistic & & $-0.776(0.015)^{* *}$ & $-0.924(0.008)^{* *}$ & $-0.059(0.004)^{* *}$ \\
\hline Threat Social & & $0.188(0.542)$ & $0.163(0.635)$ & $0.172(0.630)$ \\
\hline \multicolumn{5}{|l|}{ Altruism } \\
\hline Inclination to Donate to Charity & & $0.438(0.013)^{* *}$ & $0.466(0.013)^{* *}$ & $0.451(0.021)^{* *}$ \\
\hline Inclination to Helping Strangers & & $0.134(0.575)$ & $0.158(0.550)$ & $0.212(0.433)$ \\
\hline Inclination to Making Effort for others & & $0.137(0.543)$ & $0.163(0.522)$ & $0.234(0.370)$ \\
\hline \multicolumn{5}{|l|}{ Moderation effects } \\
\hline Knowledge of Nature Environment * Entrepreneurial Knowledge & & & $-0.342(0.368)$ & $-0.271(0.510)$ \\
\hline Knowledge of Social environment ${ }^{*}$ Entrepreneurial knowledge & & & $-0.092(0.829$ & $-0.157(0.720)$ \\
\hline Threat Biosphere * Entrepreneurial Knowledge & & & $-0.116(0.755)$ & $-0.186(0.656)$ \\
\hline Threat Egoistic * Entrepreneurial Knowledge & & & $0.365(0.528)$ & $0.427(0.494)$ \\
\hline Threat Social * Entrepreneurial Knowledge & & & $-0.230(0.642)$ & $-0.111(0.843)$ \\
\hline Inclination to Donate to Charity ${ }^{*}$ Entrepreneurial Knowledge & & & $-0.021(0.952)$ & $-0.219(0.533)$ \\
\hline Inclination to Helping Strangers * Entrepreneurial knowledge & & & $-0.727(0.048)^{* *}$ & $-0.920(0.012) * *$ \\
\hline Inclination to Making Effort for others * Entrepreneurial Knowledge & & & $-0.100(0.729)$ & $-0.370(0.399)$ \\
\hline Logistic Regression Constant & 0.219 & -0.163 & -0.114 & -3.717 \\
\hline $\mathrm{Chi}^{2}$ & 1.552 & 2.967 & 39.378 & 49.703 \\
\hline Cox \& Snell $\mathrm{R}^{2}$ & 0.007 & 0.119 & 0.164 & 0.202 \\
\hline Nagelkerke $\mathrm{R}^{2}$ & 0.009 & 0.160 & 0.219 & 0.271 \\
\hline
\end{tabular}

Note: ${ }^{*} p<0.10 ;{ }^{* *} p<0.05 ;{ }^{* * *} p<0.001 . N=220$. We applied logistic regression analysis with the dichotomous opportunity identification variable (low/high) as dependent. Interaction terms were centered to mitigate the problems of multicollinearity in moderated regression models and to facilitate interpretations. 


\subsection{Hypotheses Tests}

Model 1, in which only control variables were considered was insignificant $\left(\chi^{2}=1.552, d f=4\right.$, $N=221, p>0.1$ ), and the influence of all three control variables was also insignificant. Thus, age, gender and education do no predict the identification of sustainable opportunities. Model 2, which incorporated independent variables for testing the direct effects as in $\mathrm{H} 1, \mathrm{H} 2$, and $\mathrm{H} 2$ is significant $\left(\chi^{2}=27.949, d f=11, N=221, p<0.05\right)$. Of the eight variables introduced in Model 2 , only one is significant in the expected direction, namely inclination to donate to charity $(\beta=0.438 ; p<0.05)$, and so hypothesis $\mathrm{H} 3$ is partly supported. The remaining variables did not demonstrate any significant influence on the identification of sustainable opportunities or had a negative effect, which is the case for egoistic concerns. Hence H1 and H2 were not supported. Model 3 included control variables, independent effects and the interaction effects between entrepreneurial knowledge and independent variables. The model is significant $\left(\chi^{2}=39.378, d f=19, N=221, p<0.05\right)$. Here, only one new variable was significant, the interaction between Inclination to helping strangers and Entrepreneurial knowledge $(\beta=-0.727 ; p<0.05)$ although the effect is in the opposite direction than expected. Therefore, Hypotheses $4 \mathrm{a}, 4 \mathrm{~b}$ and $4 \mathrm{c}$ were not supported. Finally, we incorporated the direct effects of entrepreneurial knowledge in model 4 . The model is significant $\left(\chi^{2}=49.703, d f=20, N=221, p<0.001\right)$. The newly added variable, entrepreneurial knowledge is significant $(\beta=1.077 ; p<0.05)$.

\subsection{Discussion}

H1 predicts that entrepreneurs' knowledge of the natural/social environment is positively related to the identification of sustainable opportunities. The regression analysis results do not support this hypothesis, as there is an insignificant relationship between sustainable opportunity identification and knowledge of the natural environment $(p=0.230)$ as well as knowledge of the social environment $(p=0.416)$. Thus, $\mathrm{H} 1$ is fully rejected. The insignificance of the effect of knowledge of the natural/social environment is not consistent with the suggestions from the literature. An explanation for our result might be that the entrepreneurs in our sample may not seek knowledge on sustainability issues. Future research is needed to explore under which conditions (e.g., industry, country, phase of the venture, type of entrepreneur) knowledge about the natural/social environment plays a role in identifying sustainable opportunities, as there is some evidence that this knowledge indeed is important [35].

$\mathrm{H} 2$ argues that the entrepreneurs' perception of threat to the natural/social environment is positively associated with the identification of sustainable opportunities. This hypothesis is not supported as the factors related to perception of threat to the natural/social environment are almost all insignificant; "threat egoistic" is significant $(p<0.05)$, but the effect is in the opposite direction. This means that $\mathrm{H} 2$ is fully rejected, which suggests that the identification of sustainable opportunities is not influenced by the entrepreneurs' perception of threats to the natural/social environment. Follow-up studies are needed to explore why this study did not find an effect, contrary to our expectations. The lack of effect may be because many entrepreneurs are ignorant of their environmental impacts [41]. Hence, they may not be aware of the long-term impacts of social problems and environmental problems (such as ozone layer depletion, climate change, global warming). Therefore, the entrepreneurs may not pay attention to opportunities that contribute to sustaining the natural/social environment. It is also possible that high levels of threat may hinder sustainable opportunity identification because the stress experienced by entrepreneurs can lead them to inaction or to shift their attention to avoid the threat [92]. As a consequence, high levels of concerns can lead to low environmental performance [93]. Some highly concerned individuals may become subject to "environmental load"; a situation that arises when individuals are so much concerned about the environment that they believe they cannot do anything, and give up trying to act more environmentally friendly [93], consequently making it impossible for them to identify sustainable opportunities. 
In reference to $\mathrm{H} 3$, it was predicted that the entrepreneurs' altruism towards others is positively associated with the identification of sustainable opportunities. Inclination to donate to charity is significant $(p<0.05)$, while the second factor, inclination to helping strangers and the third factor, inclination to make effort for others, are insignificant. This means that $\mathrm{H} 3$ is partially supported, as one of the three altruism factors has a significant effect on the identification of sustainable opportunities. This result might be due to the limited size of our dataset, and thus future studies need to test this effect using larger datasets. Another explanation might be that most individuals in our dataset have fairly high scores for all altruism factors, more or less unrelated to how sustainable they exactly behave in their business practice, which is in line with Spence et al. [94] who noted that in the African culture, entrepreneurs naturally feel responsible for families, employees and people in their community.

In model 3, entrepreneurial knowledge was examined as a moderator between the three explanatory variables and the identification of sustainable opportunities. Only one of the interaction terms is significant (Inclination to Helping Strangers * Entrepreneurial Knowledge), but this effect is not in the expected direction. Thus, hypotheses $\mathrm{H} 4 \mathrm{a}, \mathrm{H} 4 \mathrm{~b}$ and $\mathrm{H} 4 \mathrm{c}$ are all rejected. We find no support for the hypothesis that entrepreneurial knowledge moderates the relations between knowledge of the natural/social environment, perception of threats to the natural/social environment and altruism towards others on the one hand and the identification of sustainable opportunities on the other hand. This may be because of the high levels of prior experience among the entrepreneurs in our dataset given the fact that $57.5 \%$ of our respondents had prior employment experience. While prior entrepreneurial knowledge leads to the identification of more opportunities, over time with the increase of experience the entrepreneur might get entrenched with established of knowing which limits the identification of new opportunities [57]. The positive effect on identifying sustainable opportunities vanishes as business experience increases [14].

On the other hand, the direct effect of entrepreneurial knowledge is significant in model 4, giving an indication that entrepreneurial knowledge does positively influence the identification of sustainable opportunities. This suggests that conventional prior entrepreneurial knowledge to a large extent also explains the identification of sustainable opportunities amongst entrepreneurs. This confirms that our overall study setup and results are consistent with studies from the conventional entrepreneurship literature $[57,61]$ that found that entrepreneurial knowledge increases the chance of identifying opportunities. Apparently, sustainable development opportunities form a normal subset of the total set of entrepreneurial opportunities.

\section{Conclusions}

This study set out to examine the factors positively influencing the identification of sustainable opportunities as well as to empirically test the model of Patzelt and Shepherd [12] concerning the identification of sustainable opportunities in a context where sustainability issues are quite pressing, namely the mining industry in Zambia. We focused on three explanatory factors: knowledge of the natural/social environment, perception of threat to the natural/social environment and altruism towards others, while entrepreneurial knowledge was a moderator.

Our research makes two main contributions to the domain of sustainable entrepreneurship. First, these results advance understanding how certain individuals, more than others, identify sustainable opportunities. Our empirical study reveals that altruism towards others can positively influence the identification of sustainable opportunities. Contrary to our expectations, knowledge of the natural/social environment and perception of threat to the natural/social environment do not lead to the identification of sustainable opportunities while entrepreneurial knowledge does not moderate the relationship between the three explanatory variables and the identification of sustainable opportunities. However, the direct effect of entrepreneurial knowledge on sustainable opportunity identification is significant and positive. 
Second, our study extends the conceptual work of Patzelt and Shepherd [12] by empirically testing the factors influencing the identification of sustainable opportunities. Our study shows that the model of Patzelt and Shepherd [12] can predict the identification of sustainable opportunities, but only to a very limited extent. As our research is among the first to empirically test the model of Patzelt and Shepherd [12], there is still much work to do to explore the validity and predictive power of this model. Future studies need to test whether this model has more predictive power in different settings, to explore to what extent the lack of support is due to this study's context, the Zambian mining sector. Is the rejection of hypotheses $\mathrm{H} 1, \mathrm{H} 2, \mathrm{H} 4 \mathrm{a}, \mathrm{H} 4 \mathrm{~b}$ and $\mathrm{H} 4 \mathrm{c}$ an indication that Western perspectives do not fully apply to the non-Western context? Or is the predictive power of the model in general limited, also in Western settings? Rejection of the hypotheses might be because theories derived from the Western context may not be fully applicable to developing countries because of differences in culture and economic circumstances. For instance, the effect of altruism might be different in more individualistic versus more communal societies. Hence, there is a need to consider the applicability of theories and assumptions to different contexts. There might therefore be a need to revise the model of Patzelt and Shepherd [12] by incorporating contextual variables, such as culture and economic circumstances. Follow-up studies can consider a multi-case study approach to explore why and when entrepreneurs do identify more sustainable opportunities than others; this might enable researchers to build a theory more in line with the developing country setting.

Moreover, future studies need to explore whether the model of Patzelt and Shepherd [12] needs to be extended by incorporating other variables known to influence the recognition of opportunities, such as social networks, prior business ownership, alertness and prior work experience. The inclusion of other variables will provide additional insights that will enable future researchers to extend our understanding of sustainable opportunity identification.

A limitation of our study is that we could not differentiate between types of opportunities. Future studies could focus on the type of sustainable opportunities identified (see [89]). Furthermore, we could not separate the number of sustainable opportunities identified for making an existing business more sustainable from the number of opportunities identified for starting a new sustainable business. Future researchers can explore these two lines of enquiry. Furthermore, a longitudinal study could be carried out to investigate the number of opportunities pursued or actualized.

This study has implications for practice and policy linked to sustainable entrepreneurship. As we found an effect of entrepreneurial knowledge, business associations, government, mining firms, and academic institutions should offer education and training to entrepreneurs, as this also helps them to identify more sustainable opportunities. Such general entrepreneurship training seems to have a larger effect on identifying sustainable opportunities than (only) addressing environmental and social concerns. Still, we would advice not to neglect training in environmental and social issues, as this might impact the action-orientation of entrepreneurs and impact whether they actually follow-up on the opportunities identified.

Acknowledgments: This study is partly funded by NUFFIC-NICHE as part of the HEART Project. The authors appreciate John Lungu of the Copperbelt University in Zambia for the advice and networks provided in the early stages of this research.

Author Contributions: The first author (Progress Choongo) has designed the study, collected and analyzed the data and took the lead in writing the paper. All other three authors have supported designing and writing the study. Leo Paas has also contributed by checking and improving the data analysis. All authors have read and approved the final manuscript.

Conflicts of Interest: The authors declare no conflict of interest. 


\section{Appendix 1. Definitions of Sustainable Entrepreneurship}

\begin{tabular}{|c|c|c|}
\hline Source & Definition & Dimensions \\
\hline [3] Dean \& McMullen (2007, p. 58) & $\begin{array}{l}\text { "The process of discovering, evaluating, and exploiting economic } \\
\text { opportunities that are present in market failures which detract from } \\
\text { sustainability, including those that are environmentally relevant". }\end{array}$ & Opportunities Economic Environmental \\
\hline [12] Patzelt \& Shepherd 2011 (p. 632) & $\begin{array}{l}\text { "The discovery, creation, and exploitation of opportunities to create future } \\
\text { goods and services that sustain the natural and/or communal environment } \\
\text { and provide development gain for others". }\end{array}$ & Opportunities Economic Environmental Social \\
\hline [13] Hockerts \& Wüstenhagen (2010, p. 482) & $\begin{array}{l}\text { "The discovery and exploitation of economic opportunities through the } \\
\text { generation of market disequilibria that initiate the transformation of a sector } \\
\text { towards an environmentally and socially more sustainable state". }\end{array}$ & Opportunities Economic Environmental Social \\
\hline [28] Crals and Vereeck $(2005$, p. 1) & $\begin{array}{l}\text { "The continuing commitment by business to behave ethically and contribute } \\
\text { to economic development, while improving the quality of life of the } \\
\text { workforce, their families, local communities, the society and the world at } \\
\text { large, as well as future generations. Sustainable Entrepreneurs are for-profit } \\
\text { entrepreneurs that commit business operations towards the objective goal of } \\
\text { achieving sustainability". }\end{array}$ & Economic Environmental Social \\
\hline [29] Schaltegger \& Wagner (2011, p. 224) & $\begin{array}{l}\text { "An innovative, market-oriented and personality driven form of creating } \\
\text { economic and societal value by means of break-through environmentally or } \\
\text { socially beneficial market or institutional innovations". }\end{array}$ & Economic Environmental Social \\
\hline [30] Shepherd \& Patzelt (2011, p. 142) & $\begin{array}{l}\text { "Sustainable Entrepreneurship is focused on the preservation of nature, life } \\
\text { support, and community in the pursuit of perceived opportunities to bring } \\
\text { into existence future products, processes, and services for gain, where gain is } \\
\text { broadly construed to include economic and non-economic gains to } \\
\text { individuals, the economy, and society". }\end{array}$ & Opportunities Economic Environmental Social \\
\hline [31] Choi \& Gray (2008, p. 559) & $\begin{array}{l}\text { "Create profitable enterprises and achieve certain environmental and/or } \\
\text { social } 14 \text { (2008, p. 559) objectives, pursue and achieve what is often referred to } \\
\text { as the double bottom-line or triple bottom-line". }\end{array}$ & Economic Environmental Social \\
\hline [32] Cohen \& Winn $(2007$, p. 35) & $\begin{array}{l}\text { "The examination of how opportunities to bring into existence future goods } \\
\text { and services are discovered, created, and exploited, by whom, and with what } \\
\text { economic, psychological, social, and environmental consequences". }\end{array}$ & Opportunities Economic Environmental Social \\
\hline [33] Gerlach (2003, p. 3) & $\begin{array}{l}\text { "Innovative behaviour of single or organisations operating in the private } \\
\text { business sector who are seeing environmental or social issues as a core } \\
\text { objective and competitive advantage" }\end{array}$ & Economic Environmental Social \\
\hline
\end{tabular}




\section{Appendix 2. Definitions of Developing Countries}

In this study, we used the World Bank classification of developing countries. The World Bank's classifies countries by gross national income (GNI). The World Bank classification is: low income, middle income, or high income countries. Low and middle income countries are referred to as developing countries and high income countries are considered as developed countries. So, the term developing country describes a set of low income countries (GNI per capita $\$ 1035$ or less) and middle income countries (GNI per capita between $\$ 1036$ and \$4085) in 2012 [73]. The GNI per capita for Zambia was \$1810 in 2013.

\section{References}

1. Lee, M.-D.P. A review of the theories of corporate social responsibility: Its evolutionary path and the road ahead. Int. J. Manag. Rev. 2008, 10, 53-73. [CrossRef]

2. Dean, T.J.; McMullen, J.F. Towards a theory of sustainable entrepreneurship: Reducing environmental degradation through entrepreneurial action. J. Bus. Ventur. 2007, 22, 50-76. [CrossRef]

3. Dixon, S.E.A.; Clifford, A. Ecopreneurship: A new approach to managing the triple bottom line. J. Organ. Chang. Manag. 2007, 20, 326-345.

4. Shane, S.; Venkataraman, S. The promise of entrepreneurship as a field of research. Acad. Manag. Rev. 2000, 25, 217-226. [CrossRef]

5. York, J.G.; Venkataraman, S. The entrepreneur-environment nexus: Uncertainty, innovation, and allocation. J. Bus. Ventur. 2010, 25, 449-463. [CrossRef]

6. Archichvili, A.; Cardozo, R.; Ray, S. A theory of entrepreneurial opportunity identfication and development. J. Bus. Ventur. 2003, 18, 105-123. [CrossRef]

7. Thompson, H.E.; Berrang-Ford, L.; Ford, J.D. Climate change and food security in sub-saharan Africa: A systematic literature review. Sustainability 2010, 2, 2719-2733. [CrossRef]

8. Ogalleh, S.A.; Vogl, C.R.; Eitzinger, J.; Hauser, M. Local perceptions and responses to climate change and variability: The case of Laikipia district, Kenya. Sustainability 2015, 4, 3302-3325. [CrossRef]

9. Arndt, C.; Asante, F.; Thurlow, J. Implications of climate change for Ghana's economy. Sustainability 2015, 7, 7214-7231. [CrossRef]

10. Hall, J.K.; Daneke, G.A.; Lenox, M.J. Sustainable development and entrepreneurship: Past contributions and future directions. J. Bus. Ventur. 2010, 25, 439-448. [CrossRef]

11. Pacheco, D.F.; Dean, T.J.; Payne, D.S. Escaping the green prison: Entrepreneurship and the creation of opportunities for sustainable development. J. Bus. Ventur. 2010, 25, 464-480. [CrossRef]

12. Patzelt, H.; Shepherd, D.A. Recognising opportunities for sustainable development. Entrep. Theory Pract. 2011, 35, 631-652. [CrossRef]

13. Hockerts, K.; Wüstenhagen, R. Greening Goliaths versus emerging Davids: Theorizing about the role of incumbents and new entrants in sustainable entrepreneurship. J. Bus. Ventur. 2010, 25, 481-492. [CrossRef]

14. Kuckertz, A.; Wagner, M. The influence of sustainability orientation on entrepreneurial intentions: Investigation the role of business experience. J. Bus. Ventur. 2010, 25, 524-539. [CrossRef]

15. Meek, W.R.; Pacheco, D.F.; York, J.G. The impact of social norms on entrepreneurial action: Evidence from the environmental entrepreneurship context. J. Bus. Ventur. 2010, 25, 493-509. [CrossRef]

16. Parrish, B.D. Sustainability-Driven Entrepreneurship: A Literature Review; University of Leeds: Leed, UK, 2008; Volume 9.

17. Kolk, A.; van Tulder, R. International business, corporate social responsibility and sustainable development. Int. Bus. Rev. 2010, 19, 119-125. [CrossRef]

18. Egri, C.P.; Ralston, D.A. Corporate responsibility: A review of international management research from 1998 to 2007. J. Int. Manag. 2008, 14, 319-339. [CrossRef]

19. Visser, W.; McIntosh, M.; Middleton, C. Corporate Citizenship in Africa; Greenleaf: Sheffield, UK, 2006.

20. Burgess, S.M.; Steenkamp, J.-B.E.M. Marketing renaissance: How research in emerging markets advances marketing science and practice. Int. J. Res. Market. 2006, 23, 337-356. [CrossRef]

21. Bruton, G.D.; Ahlstrom, D.; Obloj, K. Entrepreneurship in emerging economies: Where are we today and where should the research go in the future. Entrep. Theory Pract. 2008, 32, 1-14. [CrossRef] 
22. Gray, B.J.; Duncan, S.; Kirkwood, J.; Walton, S. Encouraging entrepreneurship in climate-threatened communities: A Samoan case study. Entrep. Reg. Dev. 2014, 26, 401-430. [CrossRef]

23. Lourenço, F. Promoting sustainable development: The role of entrepreneurship education. Int. Small Bus. J. 2012, 31, 841-865. [CrossRef]

24. Lichtenstein, B.B. What should be the locus of activity for sustainability? Eight emerging ecologies of action for sustainable entrepreneurship. Adv. Entrep. Firm Emerg. Growth 2011, 13, 231-274.

25. Brundtland, G.H. Report of the World Commission on Environment and Development: Our Common Future; UN: Oslo, Norway, 1987.

26. Bos-Brouwers, H.E.J. Corporate sustainability and innovation in SMEs: Evidence of themes and activities in practice. Bus. Strategy Environ. 2010, 19, 417-435. [CrossRef]

27. Dentchev, N.A. To what extent is Business and Society literature idealistic? Bus. Soc. 2009, 48, 10-38. [CrossRef]

28. Crals, E.; Vereeck, L. The affordability of sustainable entrepreneurship certification for SMEs. Int. J. Sustain. Dev. World Ecol. 2005, 12, 173-183. [CrossRef]

29. Schaltegger, S.; Wagner, M. Sustainable entrepreneurship and sustainability innovation: Categories and interactions. Bus. Strategy Environ. 2011, 20, 222-237. [CrossRef]

30. Shepherd, D.A.; Patzelt, H. The new field of sustainable entrepreneurship: Studying entrepreneurial action linking "What is to be sustained" with "What is to be developed". Entrep. Theory Pract. 2011, 35, 137-162. [CrossRef]

31. Choi, D.Y.; Gray, E.R. The venture development processes of "sustainable" entrepreneurs. Manag. Res. News 2008, 31, 558-569. [CrossRef]

32. Cohen, B.; Winn, M.I. Market imperfections, opportunity and sustainable entrepreneurship. J. Bus. Ventur. 2007, 22, 29-49. [CrossRef]

33. Gerlach, A. Sustainable Entrepreneurship and Innovation; Centre for Sustainability Management (CSM): Lueneburg, Germany, 2003.

34. Parrish, B.D. Sustainability-driven entrepreneurship: Principles of organisation design. J. Bus. Ventur. 2010, 25, 510-523. [CrossRef]

35. Rodgers, C. Sustainable entrepreneurship in SMEs: A case study analysis. Corp. Soc. Responsib. Environ. Manag. 2010, 17, 125-132. [CrossRef]

36. Isaak, R. The making of the ecopreneur. Green Manag. Int. 2002, 38, 81-91. [CrossRef]

37. Tilley, F.; Young, W. Sustainability entrepreneurs: Could they be the true wealth generators of the future? Green Manag. Int. 2009, 55, 79-92. [CrossRef]

38. Borga, F.; Citterio, A.; Noci, G.; Pizzurno, E. Sustainability report in small enterprises: Case studies in Italian furniture companies. Bus. Strategy Environ. 2009, 18, 162-176. [CrossRef]

39. Ciliberti, F.; Pontrandolfo, P.; Scozzi, B. Investigating corporate social responsibility in supply chains: A SME perspective. J. Clean. Prod. 2008, 16, 1579-1588. [CrossRef]

40. MCTI. The Micro, Small and Medium Enterprises Development Policy of Zambia; Ministry of Trade Commerce and Industry: Lusaka, Zambia, 2009.

41. Revell, A.; Stokes, D.; Chen, H. Small business and the environment: Turning over the leaf? Bus. Strategy Environ. 2010, 19, 273-288.

42. Hillary, R. Small and Medium-Sized Enterprises and the Environment; Greenleaf: Sheffield; UK, 2000.

43. Masurel, E. Why SMEs invest in environmental measures: Sustainability evidence from small and medium-sized printing firms. Bus. Strategy Environ. 2007, 16, 190-201. [CrossRef]

44. Mir, D.F.; Feitelson, E. Factors affecting environmental behavior in micro-enterprises: Laundry and motor vehicle repair firms in Jerusalem. Int. Small Bus. J. 2007, 4, 383-415. [CrossRef]

45. Russo, A.; Tencati, A. Formal vs. informal CSR strategies: Evidence from Italian micro, small, medium-sized, and large Firms. J. Bus. Ethics 2009, 85, 339-353. [CrossRef]

46. Jenkins, H. Small business champions for corporate social responsibility. J. Bus. Ethics 2006, 67, $241-256$. [CrossRef]

47. Pimenova, P.; van der Vorst, R. The role of support programmes and policies in improving SMEs environmental performance in developed and transition economies. J. Clean. Prod. 2004, 12, 549-559. [CrossRef] 
48. Kearins, K.; Collins, E.; Tregidga, H. Beyond corporate environmental management to a consideration of nature in visionary small enterprise. Bus. Soc. 2010, 49, 512-547. [CrossRef]

49. Rogers, S.H.; Gardner, K.H.; Carlson, C.H. Social capital and walkability as social aspects of sustainability. Sustainability 2013, 5, 3473-3483. [CrossRef]

50. Chendo, N.A. Managers' perception of environmental sustainability in small and medium scale enterprises (SMEs): Implication for competitive marketing advantages for sachet water manufacturers in Anambra state, Nigeria. Eur. J. Bus. Manag. 2013, 5, 186-195.

51. McKeiver, C.; Gadenne, D. Environmental management systems in small and medium businesses. Int. Small Bus. J. 2003, 23, 513-537. [CrossRef]

52. Amaeshi, K.M.; Adi, B.C.; Ogbechie, C.; Amao, O.O. Corporate social responsibility in Nigeria: Western mimicry or indigenous influences? J. Corp. Citizensh. 2006, 24, 83-99. [CrossRef]

53. Spence, L.J. Does size matter? The state of the art in small business ethics. Bus. Eth. A Eur. Rev. 1999, 8, 163-174. [CrossRef]

54. Vives, A. Social and Environmental Responsibility in Small and Medium Enterprises in Latin America; Inter-American Bank: Washington, DC, USA, 2005.

55. Casson, M. The Entrepreneur; Barnes and Noble Books: Totowa, NJ, USA, 1982.

56. Elkington, J. Cannibals with Forks: The Triple Bottom Line of 21st Century Business; Capstone: Oxford, UK, 1997.

57. Shepherd, D.A.; DeTienne, D.R. Prior knowledge, potential financial reward, and opportunity identification. Entrep. Theory Pract. 2005, 29, 91-112. [CrossRef]

58. Alsos, G.A.; Kaikkonen, V. Opportunities and Prior Knowledge: A Study of Experienced Entrepreneurs. Available online: http://papers.ssrn.com/sol3/papers.cfm?abstract_id=1768092 (accessed on 14 January 2016).

59. Ucbasaran, D.; Westhead, P.; Wright, M. The extent and nature of opportunity identification by experienced entrepreneurs. J. Bus. Ventur. 2009, 24, 99-115. [CrossRef]

60. Shane, S. Prior Knowledge and the discovery of entrepreneurial opportunities. Organ. Sci. 2000, 11, 448-469. [CrossRef]

61. Tang, J.; Kacmar, K.M.M.; Busenitz, L. Entrepreneurial alertness in the pursuit of new opportunities. J. Bus. Ventur. 2012, 27, 77-94. [CrossRef]

62. Ucbasaran, D; Westhead, P. Does entrepreneurial experience influence opportunity identification? J. Priv. Equity 2003, 7, 7-17. [CrossRef]

63. Westhead, P.; Ucbasaran, D.; Wright, M. Information search and opportunity identifcation: The importance of prior business ownership experience. Int. Small Bus. J. 2009, 27, 659-680. [CrossRef]

64. Cooper, S.R.; Park, J.S. The impact of "incubator" organizations on opportunity recognition and technology innovation in new, entrepreneurial high-technology ventures. Int. Small Bus. J. 2008, 26, 27-56. [CrossRef]

65. Nga, J.K.H.; Shamuganathan, G. The influence of personality traits and demographic factors on social entrepreneurship start up intentions. J. Bus. Ethics 2010, 95, 259-282.

66. Munasinghe, M. Analysing the Nexus of Sustainable Development and Climate Change: An Overview; OECD, Munasinghe Institute for Development (MIND): Colombo, Sri Lanka, 2003.

67. Crowson, M.L.; Debacker, T.K.; Thoma, S.J. The role of authoritarianism, perceived threat, and need for closure or structure in predicting post-9/11 attitudes and beliefs. J. Soc. Psychol. 2006, 146, 733-750. [CrossRef] [PubMed]

68. Hoffman, M.L. Is altruism part of human nature? J. Personal. Soc. Psychol. 1981, 40, 121-137. [CrossRef]

69. Simpson, B.; Willer, R. Altruism and indirect reciprocity: The interaction of person and situation on prosocial behaviour. Soc. Pschol. Q. 2008, 71, 37-52. [CrossRef]

70. De Gobbi, M.S. Mainstreaming Environmental Issues in Sustainable Enterprises: An Exploration of Issues, Experiences and Options; Employment working paper 75; International Labour Organization: Geneva, Switzerland, 2011.

71. Chamber of Mines. Enhancing Mining Contribution to Zambia's Economy and Society; The International Council of Mining and Metals (ICMM): London, UK, 2014.

72. WorldBank. How to Classify Countries. Available online: http://data.worldbank.org/about/countryclassifications (accessed on 27 November 2013).

73. Keen, C.; $\mathrm{Wu}, \mathrm{Y}$. An ambidextrous learning model for the internationalization of firms from emerging economies. J. Int. Entrep. 2011, 9, 316-339. [CrossRef] 
74. Sustainalytics. Briding Gaps: Effectively Addressing ESG Risk in Emerging Markets; Sustainalytics: Amsterdam, The Netherlands, 2012.

75. Sustainalytics. Air Pollution in China. A Hazy Future; Sustainalytics: Amsterdam, The Netherlands, 2014.

76. Dobers, P.; Halme, M. Corporate social responsibility and developing countries. Corp. Soc. Responsib. Environ. Manag. 2009, 16, 237-249. [CrossRef]

77. Dione, J. Sustainable Development Report on Africa. Managing Land-Based Resources for Sustainable Development; United National Economic Commision Africa: Addis Abeba, Ethiopia, 2012.

78. KPMG. Zambia Mining Guide. Available online: https://home.kpmg.com/xx/en/home/insights/2013/07/ zambia-country-mining-guide.html (accessed on 14 January 2016).

79. Kriauciunas, A.; Parmigiani, A.; Rivera-Santos, M. Leaving our comfort zone: Integrating established practices with unique adaptations to conduct survey-based strategy research in nontraditional contexts. Strateg. Manag. J. 2011, 32, 994-1010. [CrossRef]

80. Murad, H.; Fleischman, A.; Sadetzki, S.; Geyer, O.; Freedman, L.S. Small samples and ordered logistic regression. Am. Stat. 2003, 57, 155-160. [CrossRef]

81. Schultz, P.W.; Gouveia, V.V.; Cameron, L.D.; Tankha, G.; Schmuck, P.; Franek, M. Values and their relationship to environmental concern and conservation behaviour. J. Cross-Cult. Pychol. 2005, 36, 457-475. [CrossRef]

82. Rushton, J.P.; Chrisjohn, R.D.; Fekken, G.C. The altruistic personality and self-report altruism scale. Personal. Individ. Differ. 1981, 2, 293-302. [CrossRef]

83. Tang, J.; Murphy, P.J. Prior knowledge and new product and service introductions by entreprenerial firms: The mediating role of technological innovation. J. Small Bus. Manag. 2012, 50, 41-62. [CrossRef]

84. Otto, P.E.; Bolle, F. Multiple facets of altruism and their influence on blood donation. J. Socio-Econ. 2011, 40, 558-563. [CrossRef]

85. Hofstede, G. Culture's Consequences: Company Values, Behaviours, Institutions and Organisations Across Nations; Sage Publications: Thousand Oarks, CA, USA, 2001.

86. Hair, F.J.; Black, W.C.; Babin, B.J.; Anderson, R.E.; Tatham, R.L. Multivariate Data Analysis; Prentice Hall: New York, NJ, USA, 2014.

87. Nunnally, J.C. Psychometric Theory; McGraw-Hill: New York, NY, USA, 1978.

88. Pallant, J. SPSS Survival Manual: A Step by Step Guide to Data Analysis Using SPSS for Windows (Versions 10 and 11): SPSS Student Version 11.0 for Windows; Open University Press: Milton Keynes, UK, 2001.

89. Van Burg, E.; Podoynitsyna, K.; Beck, L.; Lommelen, T. Directive deficiencies: How resource Constraints direct opportunity identification in SMEs. J. Prod. Innov. Manag. 2012, 29, 1-12. [CrossRef]

90. Aiken, L.S.; West, S.G. Multiple Regression: Testing and Interpreting Interactions; Sage Publications: Newbury Park, CA, USA, 1991.

91. West, S.G.; Aiken, L.S.; Krull, J.L. Experimental personality designs: Analyzing categorical by continuous variable interactions. J. Personal. 1996, 64, 1-49. [CrossRef]

92. Wood, J.V.; Saltzberg, J.A.; Neale, J.M.; Stone, A.A.; Rachmiel, T.B. Self-focused attention, coping response, and distressed mood in everyday life. J. Personal. Soc. Pychol. 1990, 58, 1027-1036. [CrossRef]

93. Schaper, M. Small firms and environmental management. Int. Small Bus. J. 2002, 20, 235-249. [CrossRef]

94. Spence, M.; Gherib, J.B.B.; Biwole, V.O. Sustainable entrepreneurship: Is entrepreneurship will enough? A North-South comparison. J. Bus. Ethics 2011, 99, 335-367. [CrossRef]

(C) 2016 by the authors; licensee MDPI, Basel, Switzerland. This article is an open access article distributed under the terms and conditions of the Creative Commons by Attribution (CC-BY) license (http://creativecommons.org/licenses/by/4.0/). 